\title{
Isotope hydrology model and stable isotopes in sediment records from Balkan lakes
}

\author{
Chantzi P.* and Almpanakis K. \\ Laboratory of Physical Geography, Department of Physical \& Environmental Geography, School of Geology, Aristotle University of \\ Thessaloniki (AUTH), GR-541 24 Thessaloniki, Hellas, Greece \\ Received: 02/02/2019, Accepted: 17/03/2020, Available online: 27/05/2020 \\ *to whom all correspondence should be addressed: e-mail: pchantzi@geo.auth.gr \\ https://doi.org/10.30955/gnj.003058
}

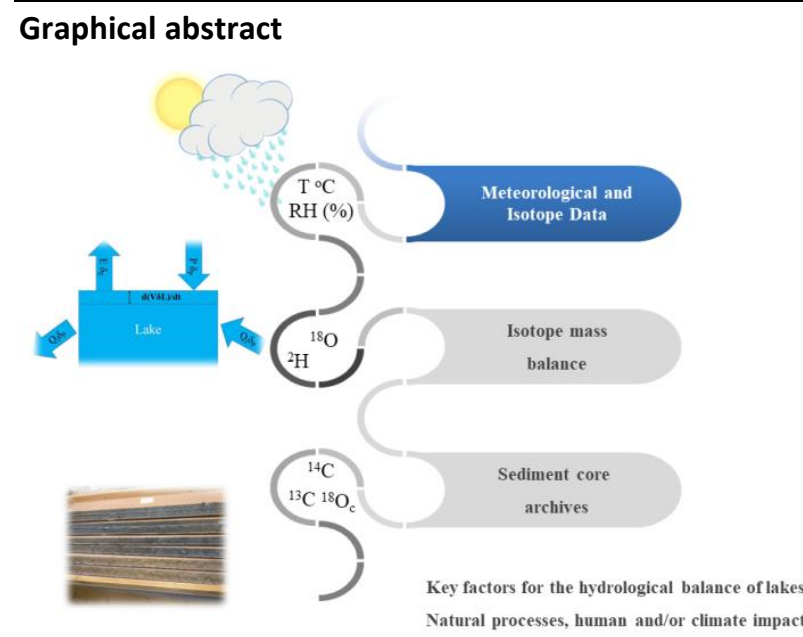

\begin{abstract}
Isotope mass balance in lake systems is strongly correlated with several climatic factors such as temperature, evaporation, precipitation and air moisture. On the other hand, the sedimentary budget of lake basins driven by climate, tectonic and/or human impact is an essential pool of environmental records. Precipitation, springs and lake water $\delta D$ and $\delta^{18} \mathrm{O}$ isotope data were used in order to understand the key factors for the hydrological balance of Balkan lakes in West Macedonia. In general, it is concluded that the open lake Ohrida and the semi-closed lake Kastoria are more buffered hydrological as karst systems and less sensitive to evaporation effect, in contrast to the closed lake system of Prespes that present a strong dependence on climate seasonality. Based on oxygen isotopes in bulk sediments, it is concluded that in Kastoria lake basin an increased run-off on the land surface, probably under a more humid period, in $2.4 \mathrm{kyr}$ BP disturbed the transition to a drier regime from $\mathrm{mid} /$ late Holocene to present.
\end{abstract}

Keywords: Lake Kastoria, Holocene, Mediterranean, Balkan, palaeoclimate, stable isotopes, sediments.

\section{Introduction}

Mediterranean area is strongly affected by climate change with a strong impact on the hydrological cycle
(Luterbacher et al., 2005; Fletcher and Zielhofer, 2013; Lelieveld et al., 2012). Several climate models end up to interannual variability for both temperature and precipitation (Giorgi, 2006). Moreover, palaeoclimatic reconstructions highlight climate and hydrology variation in Mediterranean area during Holocene. In this frame, topography, geomorphological environment, and human activities define how these complex processes balance as regards human societies. Today, it is very important to have in-depth knowledge about past climate variations and modern environment in order to build our future actions with respect to ecological and social impacts.

Lakes give the opportunity to assess climate variation as 1) they are worldwide representing different climate conditions (temperature, precipitation, moisture), geographic location (north, south), hydrology systems (open, closed, semi-closed), water types (fresh/sea water or mixing processes), 2) the response in long-term intervals including records of hydrologic extremes, 3) they are directly linked to climate variations incorporating the climate-driven episodes of their basins. Isotope mass balance in lake systems is strongly correlated with several climatic factors such as temperature, evaporation, precipitation and air moisture. The well response of isotope hydrology model to different water bodies makes it a reliable tool to assess hydrological studies. Several studies have been published regarding the estimation of water balance parameters such as evaporation (E), inflow (I) and the corresponding ratio $(E / I)$, the residence time of water in the lake (Turner et al., 2014; Narancic et al., 2017; MacDonald et al., 2017; Gibson et al., 2002; Petermann et al., 2018), and water yield (Bennett et al., 2008; Gibson et al., 2010; 2017). However, isotope mass balance approach using hydrogen $\left(\delta^{2} \mathrm{H}\right)$ and oxygen $\left(\delta^{18} \mathrm{O}\right)$ stable isotopes overcomes the lack or the limited instrumental data concluding in reliable estimations regarding different lake hydrology systems (Haig, et al., 2020). On the other hand, the sedimentary budget of lake basins driven by climate, tectonic and/or human impact is an essential pool of environmental records. In this study, we focus on oxygen isotopes ${ }^{18} \mathrm{O} /{ }^{16} \mathrm{O}$ as an ideal tracer for water cycle and its signature in bulk sediments. 
Our interest is focused in the three hydrological different lakes Ohrida, Prespes and Kastoria in south Balkans. Our main objectives are (1) to underline the correspondence of isotope mass balance model to three well-defined lakes, and (2) to reach a new conclusion about paleoclimatic conditions in Kastoria lake basin.

\section{Materials and methods}

\subsection{Isotope mass balance model for lake systems}

The isotopic mass balance (eq. 2) is based on the water mass balance (eq. 1) for a well-mixed lake with constant water density:

$$
\begin{aligned}
& d V / d t=P+Q_{i}-E-Q_{0} \\
& d(V \delta L) / d t=P \delta_{P}+Q_{i} \delta_{P}-E \delta_{E}-Q_{0} \delta_{L}
\end{aligned}
$$

where: $\mathrm{V}$ and $\mathrm{t}$, are the lake volume and unit time. $\mathrm{P}$ and $\mathrm{E}$ are precipitation and evaporation on lake surface per unit time. $Q$ factor is calculated by the surface and groundwater budget $(Q x=S x+G x)$, where $o$ and i markers correspond to outflow and inflow respectively. The isotope values of precipitation, evaporation and lake water are induced by $\delta_{P}, \delta_{E}$ and $\delta_{L}$ respectively. The results are expressed in standard delta notation $(\delta)$ as per mil (\%o) deviation from the standard V-SMOW as: $\delta=$ $\left(\left(R_{\text {sample }}-R_{\text {standard }}\right) / R_{\text {standard }}\right) \times 1000$, where $R_{\text {sample }}$ and Rstandard $={ }^{2} \mathrm{H} /{ }^{1} \mathrm{H}$ or ${ }^{18} \mathrm{O} /{ }^{16} \mathrm{O}$ of sample and standard, respectively. $\delta_{p}$ and $\delta_{L}$ are directly measurable on a water sample however it is not as easy for $\delta_{E}$. Craig and Gordon (1965) reported an evaporation model that is used to calculate $\delta_{\mathrm{E}}$ (eq. 3 ):

$$
\delta_{\mathrm{E}}=\left(\mathrm{a} * \delta_{\mathrm{L}}-\mathrm{h} \delta_{\mathrm{A}}-\varepsilon\right) /\left(1-\mathrm{h}+\varepsilon_{\mathrm{k}}\right)
$$

where, h: relative humidity normalized to the saturation vapor pressure at the temperature of the air-water interface, $\delta_{A}$ : the isotopic value of the air-vapor over the lake, $\varepsilon_{k}$ : kinetic fraction factor, for $\delta^{18} \mathrm{O}$ with $\varepsilon_{\mathrm{k}} \sim 14.2(1-\mathrm{h})$ \%o (Gonfiantini, 1986)

$$
\varepsilon=\varepsilon^{*}+\varepsilon_{k}, \text { where } \varepsilon^{*}=1000\left(1-\alpha^{*}\right)
$$

$\alpha^{*}$ : equilibrium isotopic fractionation factor dependent on the temperature at the evaporating surface

$$
\begin{aligned}
& { }^{18} \mathrm{O}: 1 / \mathrm{a}^{*}=\exp \left(1137 \mathrm{~T}_{\mathrm{L}}^{-2}-0.415 \mathrm{~T}_{\mathrm{L}}^{-1}-2.0667 * 10^{-3}\right. \\
& { }^{2} \mathrm{H}: 1 / \mathrm{a}^{*}=\exp \left(24844 \mathrm{~T}_{\mathrm{L}}^{-2}-76.248 \mathrm{~T}_{\mathrm{L}}^{-1}-52.61 * 10^{-3}\right.
\end{aligned}
$$

$\mathrm{T}_{L}$ : temperature of the lake surface water in degrees Kelvin (Majoube, 1971)

Eq. 5 describes an additional equation for $\delta_{E}$ as proposed by Benson and White (1994) based on the same evaporation theory which has been used in other lake models (Ricketts and Johnson, 1996).

$$
R_{e}=\left[\left(R_{L} / a_{e q}\right)-\left(R H f_{a d} R_{a d}\right)\right] /\left[\left((1-R H) / a_{k i n}\right)+R H\left(1-f_{a d}\right)\right]
$$

where, $\mathrm{R}_{\mathrm{ad}}$ : isotope ratio of the free atmospheric water vapor with respect to VSMOW, RH: relative humidity, and $\alpha_{\text {eq: }}$ fractionation factor dependent on equilibrium isotopic fractionation factor with $\alpha_{\text {eq }}=\left(1 / \alpha^{*}\right), \alpha_{\text {kin }}$ : fractionation factor dependent on wind speed where $\alpha_{\text {kin }}$ $=0.994$ for wind speeds less than $6.8 \mathrm{~m}^{*} \mathrm{~s}^{-1}$ (Merlivat and

\begin{tabular}{|c|c|c|c|c|c|c|c|c|c|}
\hline & $\mathrm{T}_{\mathrm{av}}\left({ }^{\circ} \mathrm{C}\right)$ & $\delta^{18} O_{p} \%$ VSMOW & Altitude (m asl) & RH (\%) & d-excess & (1) $\delta^{18} \mathrm{O}_{\mathrm{L}}$ & (2) $\delta^{18} \mathrm{O}_{\mathrm{L}}$ & (3) $\delta^{18} \mathrm{O}_{\mathrm{L}}$ & Mean $(1,2) \delta^{18} O_{L}$ \\
\hline Pedeli Athens & 15.2 & -7.48 & 451 & 71 & 14.98 & -4.65 & 4.40 & -2.89 & 0.76 \\
\hline Thessaloniki & 16 & -6.69 & 93 & 71 & 9.03 & -3.81 & 5.16 & -2.01 & 1.57 \\
\hline Patra & 18.1 & -5.78 & 112 & 65 & 10.99 & -2.39 & 6.23 & -0.26 & 2.99 \\
\hline Edirne, Turkey & 15 & -8.24 & 80 & 71 & 11.58 & -5.4 & 3.66 & -3.63 & 0.01 \\
\hline${ }^{a}$ Mean SW & 20.6 & -9.305 & 0 & 38 & - & -2.27 & 5.64 & 1.55 & 3.60 \\
\hline
\end{tabular}
Jouzel, 1979), $\mathrm{fad}_{\mathrm{ad}}$ : fraction of atmospheric water vapor in the boundary layer over the lake where $f_{a d}=0$ in case that all the atmospheric water overlying the lake is derived from evaporation, rather than atmospheric moisture.

Table 1. Summary of average annual hydro-climate factors from GNIP (IAEA/WMO, 2017) data and calculated $\delta^{18} \mathrm{O}_{\mathrm{L}}$ values for hydrologically closed lakes from Chantzi and Almpanakis, 2018

a: Gat et al., 1996; (1): values from Eq3 that corresponds better to the period with high water-table as it cannot render accurately the evaporation process; (2): values from Eq. 6 with Fad $=0$ that correspond to water vapor of evaporation origin; (3): values from Eq. 6 with $\mathrm{Fad}=0$ that correspond to water vapor of atmospheric moisture origin

Finally, $\delta_{E}$ is calculated by $\delta_{i}=\left(R_{i}-1\right) 10^{3}$ and $R_{i}=$ $\left(R_{i} / R_{\text {standard }}\right)$ where $R$ is the isotope ratio and the standard, in this case, is VSMOW.

\subsection{Methodology}

Limnological isotope theory (Leng and Marshall, 2004; Roberts et al., 2008) is based on climatic factors and precipitation-evaporation balance $(P / E)$ for hydrological open and closed lake systems. In the first case, the origin of precipitation and temperature oscillations determine the isotopic signature of lake water $\left(\delta^{18} \mathrm{OLW}\right)$ instant of the precipitation-evaporation balance $(P / E)$ that is the key factor for hydrological closed lakes. The origin of atmospheric water vapor in the boundary layer over the lake plays an important role in the isotopic signature of lake waters (equations of Benson and White, 1994; Ricketts and Johnson, 1996). In fact, the actual mechanism is a continuous refresh where the air above the lake constantly supplies the evaporation process permitting molecules to pass from the liquid to vapor phase and leaving the lake surface. The main incoming air flow pattern in the Mediterranean area is controlled by the Atlantic Ocean through the Iberian Peninsula or France (for the western Mediterranean) or from the European continent (for the eastern Mediterranean). Table 1 shows IAEA stations with average annual hydro-climate factors from GNIP (IAEA/WMO, 2017) data and calculated $\delta^{18} \mathrm{O}_{\mathrm{L}}$ values for hydrologically closed lakes. The selection of 
these stations made considering the precipitation pattern in the Mediterranean and particularly to the study areas. The higher precipitation recharge found in the western part of Greece with the contribution of orographic injections of Pindos Mountains and the mountains of the Peloponnese. Eastern Aegean comes second where the complex topography and the warm Aegean Sea result in a considerable precipitation recharge. These significant precipitation amounts attributed to the depressions of Atlantic or western and central Mediterranean origin that enter Greece on the west during their eastwards route generating south-southwest wind over the Ionian Sea and southern Greece resulting in reduced precipitation recharge in Central Greece (Figure 1).

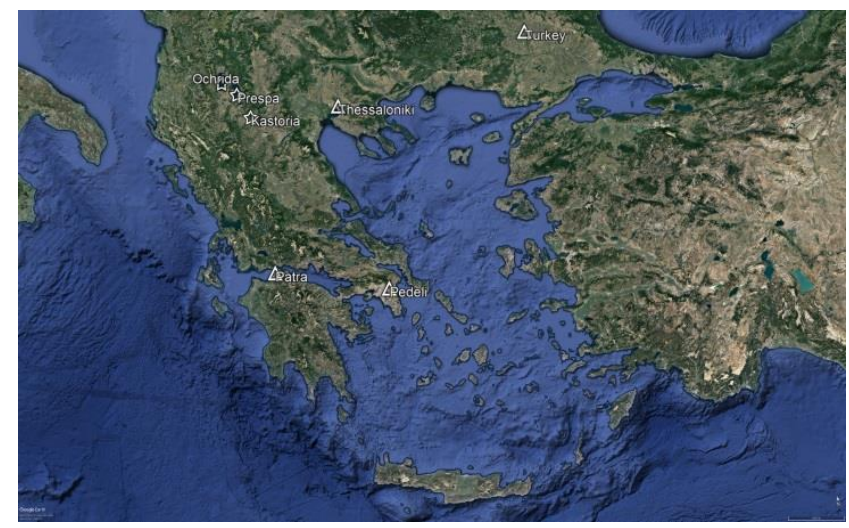

Figure 1. Study lake with marked lakes and IAEA precipitation station. White Star: lake sites; white triangle: GNIP (IAEA/WMO, 2017)

\section{Results and discussion}

\subsection{Isotope hydrology}

In order to trace the changes of the hydrological cycle in the sediments, we first need to completely deconstruct the hydraulic behavior of the three lake systems. Kastoria, Ochrid and Prespes belong to a large complex of lakes in NW Macedonia of Neogene-Quaternary origin and they are situated in a tectonic graben formed during the latest phases of Alpine orogeny (Vafeiadis P., 1983). The geological formation found are Palaeozoic metamorphic, semi-metamorphic and magmatic rocks of the entire western Macedonian Zone, carbonate rocks of Mesozoic (Triassic - Jurassic) period and Cenozoic sediments including Pliocene and Quaternary alluvial loose deposits. Long term water isotope data in the wider area (Figure 3) present a range from $-11.1 \%$ o to $-8.7 \%$ for $\delta^{18} \mathrm{O}$ and from $-69.2 \%$ to $-50.1 \%$ ofor $\delta \mathrm{D}$ with respect to precipitation data. Springs present mean $\delta^{18} \mathrm{O}$ and $\delta D$ values about $-8.2 \%$ and $-57.7 \%$ o respectively. Each lake refers to a different hydrological status with different hydrological balance (Figure 2).

Kastoria lake surrounded by Verno, Askio, Korissos and Vigla mountains and belongs to Aliakmonas river basin. The isotopic gradient of the basin estimated $-0.12 \% / 100 \mathrm{~m}\left(\delta^{18} \mathrm{O} \% \mathrm{o} / 100 \mathrm{~m}\right)$ (Table 2$)$ lower than that Leontiadis (1992) reported $-27 \% / 100 m$ for the east part of western Macedonia, driven by different proxies such as air masses flow pattern, temperature, orography, topography, and geomorphology. The contribution of Kastoria lake water in groundwaters at the southern part of the basin is remarkable. Detailed, the underground $(35 \mathrm{~m})$ aquifer located at $630 \mathrm{~m}$ altitude in the south-west part of Kastoria Lake basin and circulates in limestones of Middle-Upper Liasio, a land division that discharges in the center of the lake, presents mean $\delta^{18} \mathrm{O}_{w}$ value $-8.5 \%$. The recharge altitude for this area estimated at $895 \mathrm{~m}$ with $\delta^{18} O_{w}=-9.4 \%$, justifying $\delta^{18} O_{w}=-9.04 \%$ o values which are more depleted than $-8.5 \%$ of groundwater aquifer suggesting a contribution of lake water $\left(\delta^{18} \mathrm{O}_{\mathrm{L}}=-1.3 \%\right.$ ) about 5\%. Accordingly, at the south part, close Dispilio, with recharge altitude $740 \mathrm{~m}$ and $\delta^{18} \mathrm{O}_{w}=-9.2 \%$, spring water with $\delta^{18} \mathrm{O}_{\mathrm{w}}=-8.4 \%$ o suggests a contribution of lake water about $6 \%$. Finally, Militsa and Istekos springs at the south-east part of the basin correspond to the isotopic gradient. The hydrographic network is characterized by many rivers (Xiropotamos, Vissinias) and streams that inflow the lake. However, it is interesting that Gioli river functions as an overflow channel to Aliakmonas river, which characterize Kastoria lake as a semi-closed system.

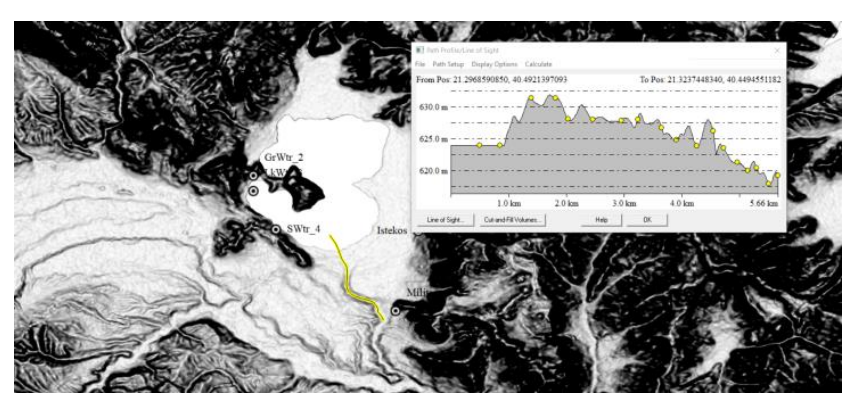

Figure 2. Detailed map of surface and groundwater samples in the south part of Kastoria basin listed in Table 2.

Table 2. Oxygen isotope values for surface and groundwater samples in the south part of Kastoria basin (Chantzi, 2017)

\begin{tabular}{ccc}
\hline Sample stations & Altitude/depth $(\mathbf{m})$ & $\boldsymbol{\delta}^{\mathbf{1 8}} \mathbf{O} \%$ VSMOW \\
\hline GrWtr_2 & $630 / 35$ & -8.5 \\
\hline LkWtr_3 & 629 & 1.3 \\
\hline SWtr_4 & 630 & -8.4 \\
\hline Militsa & 627 & -9.5 \\
\hline Istekos & 625 & -9.2 \\
\hline Recharging zone I & 740 & -9.2 \\
\hline Recharging zone II & 895 & -9.4 \\
\hline Recharging zone III & 1050 & -9.5 \\
\hline
\end{tabular}

Ohrida and Prespes lakes are well documented regarding their isotopic and hydrological model (Popovska et al., 2007; Leng, 2010; Hoffmann et al., 2012; Lacey et al.,
2015). Ohrida is an open lake where the main hydrological output (about 66\%) is through the River Black Drin to the northern shore and the rest is lost through evaporation 
and seepage (Matzinger et al., 2006). Mean oxygen isotope values $\delta^{18} \mathrm{O}_{\mathrm{L}}$ for Ohrida and Prespes lake are about $-3.5 \%$ and $-2 \%$ respectively. Previous studies (Popovska et al., 2007; Leng, 2010; Anovski, 2001) have reported that Prespes supply Ohrida through the karst massifs of the mountains Galicica and Suva Gora located between them. However, Prespes do not present surface outflow therefore considered as a closed system. In general, it is concluded that the open lake Ohrida and the semi-closed lake Kastoria are more buffered hydrological as karst systems and less sensitive to evaporation effect, in contrast to the closed lake system of Prespes that present a strong dependence on climate seasonality. This is also clear from the local evaporation line (Figure 3) where Kastoria and Ohrida present $\delta \mathrm{D} / \delta^{18} \mathrm{O}$ ratio about 5.14 and 5.2 respectively, while Prespes system present $\delta D / \delta^{18} \mathrm{O}$ ratio about 4.95 reflecting a more intensive evaporation effect.

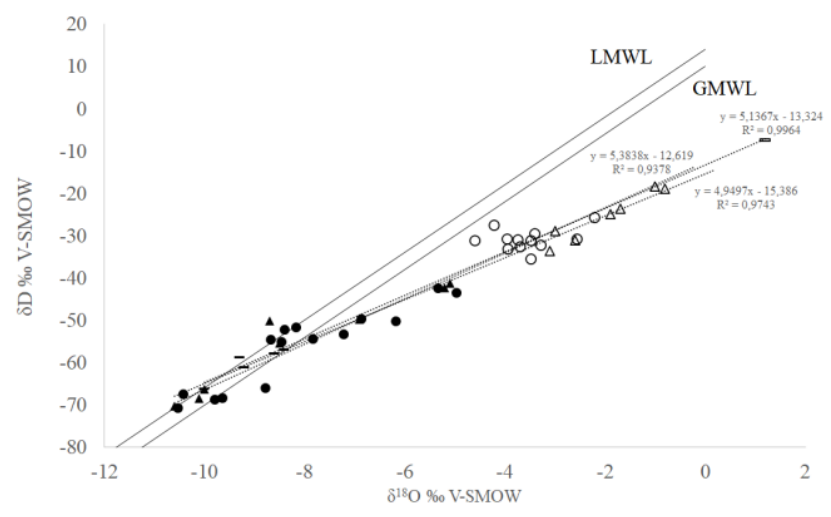

Figure 3. The isotopic $\left(\delta^{18} \mathrm{O}\right.$ and $\left.\delta \mathrm{D}\right)$ composition of modern waters from springs and precipitation data around Balkan study sites, as well as the lakes themselves. The Global Meteoric Water Line (GMWL: Craig H., 1961) and the Local Meteoric Water Line (LMWL: Eftimi and Zoto, 1997) are also given. [Closed: precipitation and springs; Open: lake water; circle: lake Ohrida (Leng et al., 2010); triangle: Lake Prespes (Anovski, 2001); rectangle: Lake Kastoria (Chantzi, 2017)]

Table 1 summarizes the calculated $\delta^{18} \mathrm{O}_{\mathrm{L}}$ based on isotope hydrology equations. Mean measured value $\delta^{18} \mathrm{O}_{\mathrm{L}}=-3.5 \%$ for Ohrida lake is very closed to the calculated value $\delta^{18} \mathrm{O}$ $=-3.8 \%$ from Thessaloniki station for the equation that corresponds better to higher water-table as it cannot render accurately the evaporation process. This is consistent with the higher depth of Ohrida lake (mean $150 \mathrm{~m}$ ) and its open hydrological status. So, Thessaloniki IAEA station is appropriate to proceed in interpretation. Mean measured value $\delta^{18} \mathrm{O}_{\mathrm{L}}=-2 \%$ o for the Prespes lake systems totally meet the calculated value $\delta^{18} \mathrm{O} \mathrm{L}=-2.0 \%$ o from Thessaloniki station for the equation that corresponds better to water vapor of atmospheric moisture origin. Prespes present a strong seasonality as a closed lake system. As we discussed above Prespes are more influenced by the evaporation process in relation to Ohrida, however, it is a much shallower system (mean $15 \mathrm{~m}$ ) which is mainly fed by surface runoff and precipitation. Moreover, the recharge of the springs and rivers is mainly supported by winter precipitation defining the lake levels and the isotope composition of the Prespa lakes (Hollis and Stevenson, 1997). Measured $\delta^{18} \mathrm{O}_{\mathrm{L}}=$ $1.3 \%$ for Kastoria lake is the more positive value between the three lakes. Unfortunately, we have no available long dataset from Kastoria lake, however, this positive value could be attributed to high lake water resistance time. This means that this value reflects a long history of cycles between atmospheric moisture and evaporation vapors. Therefore, this measured value for Kastoria lake is closed to the mean value $\delta^{18} \mathrm{O}_{\mathrm{L}}=1.6 \%$ from Thessaloniki station for the two equations that correspond to water vapor of both atmospheric moisture and evaporation origin. What we stressed above all is that isotope mass balance for oxygen values corresponds very well to primary data reflecting the well-defined processes of these lake systems.

\subsection{Oxygen isotope in lacustrine sediments}

Figure 4 shows oxygen isotope values of bulk sediments among the different discussed sites in the Holocene period. The factors that control the isotopic signals in lacustrine sediments are bulk carbonates with different origin particles, the hydrological regime and water temperature under which the calcite precipitates, and finally the biological activity that influences the carbonate chemistry. Carbon and oxygen isotope ratios on authigenic carbonates highlight climate oscillations. The formation of calcium carbonate depends on the concentration of bicarbonate of calcium ions in water and it is characterized by the following reaction: $\mathrm{Ca}_{2}{ }^{+}+2 \mathrm{HCO}_{3}{ }^{-}$ $\leftrightarrow \mathrm{CaCO}_{3(\mathrm{~s})}+\mathrm{H}_{2} \mathrm{O}+\mathrm{CO}_{2}$. The main factor that controls the carbonate precipitation is the intake of $\mathrm{CO}_{2}$ during photosynthesis process from aquatic macrophytes and phytoplankton. Variations in $\delta^{18} \mathrm{O}_{c}$ of lacustrine carbonates are interpreted as changes in the precipitation/evaporation ratio (Siegenthaler and Oeschger, 1980) and based on the assumption that in lake systems the calcite precipitates in known isotopic equilibrium (Epstein et al., 1953; Friedman et al., 1977). In small open lakes the sediments do not present large variations in $\delta^{18} \mathrm{O}_{c}$ values and are mainly attributed to temperature changes during the precipitation of carbonates, reflecting a seasonal signal. This is typical for Ohrida lake that exhibits $\delta^{18} \mathrm{O}_{\mathrm{c}}$ values without strong variations. In closed basins repeated cycles with more positive $\delta^{18} \mathrm{O}_{c}$ values highlight drier periods while more negative $\delta^{18} \mathrm{O}_{\mathrm{c}}$ values reflect wetter periods (Talbot and Kelts, 1990). The high stratigraphic variability of $\delta^{18} \mathrm{O}_{c}$ values from Prespes closed lake system in the middle and late Holocene totally reflects the climate variation from wetter to drier conditions and vice versa. The Holocene paleoclimatic regime of Ohrida and Prespes lakes has been reconstructed in detail and its not part of this study. What we would like to impose is that $\delta^{18} \mathrm{O}_{c}$ variability aligns with the well-defined hydrological status (open and closed) of these lakes. This point needs to be made in order to proceed to Kastoria lake.

The basin of Kastoria lake belongs to an intermediate zone between the Mediterranean and European Continental climatic region. The winter is harsh often with frost 
episodes while in summer the temperature often reaches $40{ }^{\circ} \mathrm{C}$. Mean annual temperature is $12.5{ }^{\circ} \mathrm{C}\left(2.4{ }^{\circ} \mathrm{C}\right.$ in January and $22.8{ }^{\circ} \mathrm{C}$ in July) and annual precipitation ranging between $770 \mathrm{~mm}$ to $1000 \mathrm{~mm}$. The area is characterized by high humidity in winter months (over $80 \%$ from December to February) while it is drier in summer months (50-55\% during June to August). Considering the mean annual temperature of the basin, the proposed equation by Hays and Grossman (1991) for the inland station and $\delta^{18} \mathrm{O}_{\text {sw }}(\mathrm{SMOW})=0 \%$ :

$$
\delta^{18} \mathrm{O}_{\mathrm{c}(\mathrm{PDB})}=-14.43+1.099 * \mathrm{~T}\left({ }^{\circ} \mathrm{C}\right)-3.08 * 10^{-2} * \mathrm{~T}^{2}\left({ }^{\circ} \mathrm{C}\right)-\delta^{18} \mathrm{O}_{\text {sw(SMOW })}
$$

gives us $\delta^{18} \mathrm{O}_{c}$ values of modern calcite about $-5.5 \%$ o PDB. For Ohrida lake modern calcite have reported about 4.5\% (Lacey et al., 2015)

Generally, $\delta^{18} \mathrm{O}_{\mathrm{c}}$ values of bulk sediments from the southern part of the Kastoria lake present a large variation between more negative values than the modern one. Figure 4 shows two main periods: the transition to wetter conditions until $4.7 \mathrm{kyr} \mathrm{BP}$ and then the transition to drier conditions from 4.7 kyr BP to present. In fact, this shift to a drier regime in $\mathrm{mid} /$ late Holocene is disturbed by wetter fluctuations (2.4 kyr BP and 3.5 kyr BP). Particularly, the extreme value in $2.4 \mathrm{kyr}$ BP exhibits the most negative value of all data implying the presence of significant contribution of clastic carbonates. Chantzi et al., 2017b describe in detail the higher sedimentation rates this period attributed to the destruction (e.g. local deforestation) of natural control mechanisms probably under a wetter period. It is worth noting that these observations for $\mathrm{mid} /$ late Holocene have also been reported for Ohrida (Lacey et al., 2015), Prespes (Leng et al., 2013) and Shkodra (Zanchetta et al., 2012) lake in the wider area of western Macedonia. These Holocene variations are also visible in sediment records from Dead Sea where two long wet periods exist $(10-8.6 \mathrm{k \alpha l}$ 5.6-3.5 cal kyr BP), with multiple abrupt episodes of more dry conditions (8.6, 8.2, 4.2, 3.5 cal kyr BP) (Migowski et al., 2006). Carbon isotope data from sediment records in north Aegean highlighted a wetter period, as well, close to $4.5 \mathrm{kyr}$ B.P (Kuhnt, T et al., 2008) while Triantaphyllou et al., 2009 suggest that the increased precipitation in the interval 5-4 kyr BP may have led to the formation of a younger Sapropel in mid Holocene (SMP) in the southern Aegean. Although $\delta^{18} \mathrm{O}_{\mathrm{c}}$ values of bulk sediments highlighted an increased run-off on the land surface under a more humid period, we can't use these records as raw-data and pure paleolimnology proxies for changes in the lake recharge patterns because authigenic carbonate signature is not clear. However, Zanchettas et al., 2012 reported that the temperature effect on rainfall for Mediterranean stations $\left(0.2 \% \circ{ }^{\circ} \mathrm{C}^{-1}\right.$, Bard et al., 2002) and on calcite precipitation $\left(-0.2 \%{ }^{\circ} \mathrm{C}^{-1}\right.$, Kim and O'Neil, 1997) could cancel out each other. This allows us to use $\delta^{18} \mathrm{O}_{c}$ values of bulk sediments as nearpure signal. The distribution of $\delta^{18} \mathrm{O}_{\mathrm{c}}$ values during midHolocene reflect on the one hand a closed hydrologically lake that responses on climate variation, however, with more negative values reflecting the influence of precipitation data as an open lake. But, at this time period, eastern Mediterranean lakes present in general low and stable $\delta^{18} \mathrm{O}_{\text {calcite }}$ values (Zanchetta et al., 2007; Robert et al., 2008). In any case we cannot further proceed to the interpretation of the past hydrologically status of the Kastoria lake because of the lack of both number and quality samples.

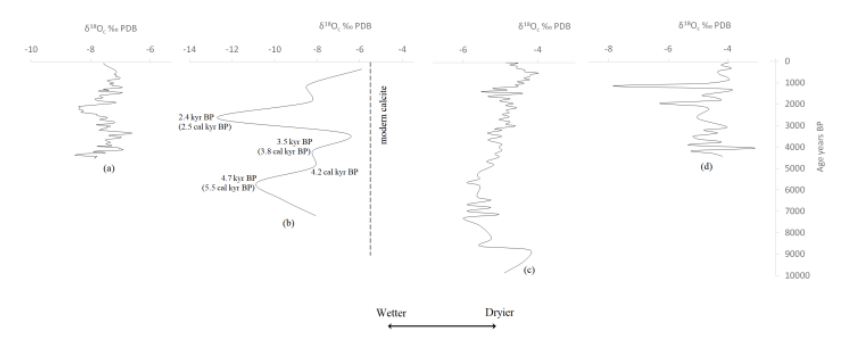

Figure 4. Comparison of $\delta^{18} \mathrm{O}_{\mathrm{c}}$ of bulk sediments among the different discussed sites a) Lake Shkodra (Zanchetta et al., 2012);

b) Lake Kastoria (Chantzi et al., 2017a); c) Lake Ochrida core

1202 (Roberts et al., 2008); d) Lake Prespa (Leng et al., 2010)

\section{Conclusions}

Precipitation, springs and lake water $\delta D$ and $\delta^{18} O$ isotope data were used in order to understand the key factors for the hydrological balance of western Macedonia lakes. In general, it is concluded that the open lake Ohrida and the semi-closed lake Kastoria are more buffered hydrological as karst systems and less sensitive to evaporation effect, in contrast to the closed lake system of Prespes that present a strong dependence on climate seasonality. This is also clear from the local evaporation line (Figure 3 ) where Kastoria and Ohrida present $\delta D / \delta^{18} \mathrm{O}$ ratio about 5.14 and 5.2 respectively, while Prespes system present $\delta \mathrm{D} / \delta^{18} \mathrm{O}$ ratio about 4.95 reflecting a more intensive evaporation effect. What we stressed above all is that isotope mass balance for oxygen values corresponds very well to primary data reflecting the well-defined processes of these lake systems. Therefore, any estimation about the past or the future response of lake systems to climate variation requires the in-depth knowledge of modern basin processes. Regarding $\delta^{18} \mathrm{Oc}$ values of bulk sediments in Kastoria lake, we underlined two major trends: the transition to wetter conditions until $4.7 \mathrm{kyr}$ BP and then the transition to drier conditions from $4.7 \mathrm{kyr} B P$ to present. In fact, this shift to a drier regime in $\mathrm{mid} /$ late Holocene is disturbed by wetter fluctuations (2.4 kyr BP and $3.5 \mathrm{kyr} \mathrm{BP}$ ) with an increased run-off on the land surface under a more humid period in $2.4 \mathrm{kyr}$ BP. Kastoria lake seams to function as a semi-closed lake without any prolonged prevalence of the one or the other hydrological status with respect to climate proxies. Finally, this study concludes that mass balance isotope model enables us to interpret paleoclimatic variations beyond the instrumental data, however, it requires reliable raw datasets of modern climatic and isotope data. 


\section{References}

Anovski T. (ed). (2001), Progress in the Study of Prespa Lake using Nuclear and Related Techniques, Project Report, IAEA Regional, Project RER/8/008. Skopje, Macedonia.

Bennett K.E., Gibson J.J. and McEachern P.M. (2008), Water-yield estimates for critical loadings assessment: Comparisons of gauging methods versus an isotopic approach, Canadian Journal of Fisheries and Aquatic Sciences, 65, 83-99.

Benson L.V. and White J.W.C. (1994), Stable isotopes of oxygen and hydrogen in the Truckee River Pyramid Lake surfacewater system 3. Source of water-vapour overlying Pyramid Lake, Limnology and Oceanography, 39, 1945-1958.

Bond G., Kromer B., Beer J., Muscheler R., Evans M.N., Showers W., Hoffmann S., Lotti-Bond R., Hajdas I., Bonani G., et al. (2001), Persistent solar influence on North Atlantic climate during the Holocene, Science, 294, 2130-2136.

Chantzi P., Dotsika E., Albanakis K. and Kotsakis K. (2017b), Stable Isotope and Radiocarbon Analysis in Animal Bones from the Prehistoric Settlement of Dispilio, Kastoria Lake, Northern Greece, Radiocarbon, 59(6), 1629-1644.

Chantzi P. (2017), Study of paleohydrological and paleoclimatic conditions in Kastoria Lake Basin using isotope geochemistry methods, PhD Thesis, Aristotle University of Thessaloniki, p. 220.

Chantzi P. and Albanakis K. (2018), Stable isotope mass balance to assess climate impact in lake systems, International Conference "Protection and Restoration XIV", 3-6 of July, Thessaloniki, Greece, pp. 835-846.

Chantzi P., Dotsika E. and Albanakis K. (2017a), $\delta^{15} \mathrm{~N}, \delta^{18} \mathrm{O}$ and $\delta^{13} \mathrm{C}$ isotopes in sedimentary material from Dispilio excavation, north Greece, Paper ID: cest2017_00410 in 15th International Conference on Environmental Science and Technology, CEST2017, 31 August - 2 September 2017, Rhodes, Greece.

Craig H. (1961), Isotopic variation in meteoric waters, Science, 133, 1702-1703.

Craig H. and Gordon L.I. (1965), Deuterium and oxygen-18 variation in the ocean and marine atmosphere, Stable isotopes in Oceanography Studies and Paleotemperatures. Laboratorio di Geologia Nucleare, Pisa.

Eftimi R. and Zoto J. (1997), Isotope study of the connection of Ohrid and Prespa lakes, In: International Symposium "Towards Integrated Conservation and Sustainable Development of Transboundary Macro and Micro Prespa Lakes", Korcha, Albania.

Epstein S., Buchsbaum R., Lowenstam H.A. and Urey H.C. (1953), Revised carbonate water isotopic temperature scale, Geological Society of America Bulletin, 64, 1315-1326.

Fletcher W.J. and Zielhofer C. (2013), Fragility of Western Mediterranean landscapes during Holocene rapid climate changes, Catena, 103, 16-29.

Friedman I. and O'Neil J.R. (1977), Compilation of stable isotope fractionation factors of geochemical interest: Data of geochemistry, Geological Survey Professional Pap. 440-KK, U.S. Government Printing Office.

Gibson J.J., Birks J.S., Jeffries D.S., Kumar S., Scott K.A., Aherne J. and Shaw P.D. (2010), Site-specific estimates of water yield applied in regional acid sensitivity surveys across western, Canada Journal of Limnology, 69, 67-76.

Gibson J.J., Birks S.J., Jeffries D. and Yi Y. (2017), Regional trends in evaporation loss and water yield based on stable isotope mass balance of lakes: the Ontario Precambrian Shield surveys, Journal of Hydrology, 544, 500-510.

Gibson J.J. and Edwards T.W. (2002), Regional water balance trends and evaporation-transpiration partitioning from a stable isotope survey of lakes in northern Canada, Global Biogeochemical Cycles, 16.

Giorgi F. (2006), Climate change hot-spots, Geophysical Research Letters, 33, L08707

Gonfiantini R. (1986), Environmental isotopes in lake studies, In: Fritz P. and Fontes J.-C. (Eds.), Handbook of Environmental Isotope Geochemistry Volume 2B, Elsevier, Amsterdam.

Haig H.A., Hayes N.M., Simpson G.L., Yi Y., Wissel B., Hodder K.R. and Leavitt P.R. (2020), Comparison of isotopic mass balance and instrumental techniques as estimates of basin hydrology in seven connected lakes over 12 years, Journal of Hydrology $X, 6,100046$.

Hays P.D. and Grossman F.I. (1991), Oxygen isotopes in meteoric calcite cements as indicators of continental palaeoclimate, Geology, 19, 441-444.

Hoffmann N., Reicherter K., Grützner C., Hürtgen J., Rudersdorf A., Viehberg F.A. and Wessels M. (2012), Quaternary coastline evolution of Lake Ohrid (Macedonia/Albania), Central European Journal of Geosciences, 4(1), 94-110.

Hollis G.E. and Stevenson A.C. (1997), The physical basis of the lake Mikri Prespa systems: geology, climate, hydrology and water quality, Hydrobiologia, 351, 1-19.

IAEA/WMO (2017), Global Network of Isotopes in Precipitation, The GNIP Database, Accessible at: https://nucleus.iaea.org/wiser

Kim S.T. and O'Neil J.R. (1997), Equilibrium and non-equilibrium oxygen isotope effects in synthetic carbonates, Geochimica et Cosmochimica Acta, 61, 3461-3475.

Kuhnt T., Schmiedl G., Ehrmann,W., Hamann Y. and Hemleben C. (2007), Deep-sea ecosystem variability of the Aegean Sea during the past $22 \mathrm{kyr}$ as revealed by Benthic Foraminifera, Marine Micropaleontology, 64, 141-162.

Lacey J.H., Francke A., Leng M.J., Vane C.H. and Wagner B. (2015), A high-resolution late glacial to Holocene record of environmental change in the mediterranean from lake Ohrid (Macedonia/Albania), International Journal of Earth Sciences, 104(6), 1623--1638.

Lelieveld J., Hadjinicolaou P., Kostopoulou E. et al. (2012), Climate change and impacts in the eastern Mediterranean and the Middle East, Climatic Change 1, 14(3-4), 667-87.

Leng M.J., Baneschi I., Zanchetta G., Jex C.N., Wagner B. and Vogel H. (2010), Late Quaternary palaeoenvironmental reconstruction from Lakes Ohrid and Prespa (Macedonia/Albania border) using stable isotopes, Biogeosciences, 7, 3109-3122.

Leng M.J. and Marshall J.D. (2004), Palaeoclimate interpretation of stable isotope data from lake sediment archives, Quaternary Science Reviews, 23, 811-831.

Leontiadis I.L., Stamos A. and Manakos A. (1992), Isotope hydrology study of the wider area of Kozani, Greece, Proc. 6 th Int. Symposium on water tracing, Karlsruhe, pp. 233240.

Luterbacher J., Xoplaki E., Casty C., Wanner H., Pauling A., Küttel M., Rutishauser T., Brönnimann S., Fischer E., Fleitmann D., González-Rouco F.J., García-Herrera R., Barriendos M., Rodrigo F., Gonzalez-Hidalgo J.C., Saz M.A., Gimeno L., Ribera P., Brunet M., Paeth H., Rimbu N., Felis T., Jacobeit J., 
Dünkeloh A., Zorita E., Guiot J., Türkes M., Alcoforado M.J., Trigo R., Wheeler D., Tett S., Mann M.E., Touchan R., Shindell D.T., Silenzi S., Montagna P., Camuffo D., Mariotti A., Nanni T., Brunetti M., Maugeri M., De Zerefos C., Zolt S. and Lionello P. (2005), Mediterranean climate variability over the last centuries: a review, In: Lionello P., Malanotte-Rizzoli P. and Boscolo R. (Eds.) The Mediterranean Climate: An Overview of the Main Characteristics and Issues, Elsevier, Amsterdam (The Netherlands), pp. 27-148.

MacDonald L.A., Wolfe B.B., Turner K.W., Anderson L., Arp C.D., Birks S.J., Bouchard F., Edwards T.W., Farquharson N., Hall R.I., McDonald I., Narancic B., Ouimet C., Pienitz R., Tondu J. and White H. (2017), A synthesis of thermokarst lake water balance in high-latitude regions of North America from isotope tracers, Arctic Science, 3, 118-149.

Majoube F. (1971), Fractionnement en oxygène-18 et un deutérium entre l'eau et sa vapeur, Journal de Chimie Physique, 187, 1423-1436.

Matzinger A., Spirkovski Z., Patceva S. and Wüest A. (2006), Sensitivity of ancient Lake Ohrid to local anthropogenic impacts and global warming, Journal of Great Lakes Research, 32(1):158-179

Merlivat L. and Jouzel J. (1979), Global climatic interpretation of the $D^{18} \mathrm{O}$ relationship for precipitation, Journal of Geophysical Research, 84, 5029-5033.

Migowski C., Stein M., Prasad S., Negendank J. and Agnon A. (2006), Holocene climate variability and cultural evolution in the Near East from the Dead Sea sedimentary record, Quaternary Research, 66(3), 421-431.

Narancic B., Wolfe B.B., Pienitz R., Meyer H. and Lamhonwah D. (2017), Landscape-gradient assessment of thermokarst lake hydrology using water isotope tracers, Journal of Hydrology, 545, 327-338.

Petermann E., Gibson J.J., Knöller K., Pannier T., Weiß H. and Schubert M. (2018), Determination of groundwater discharge rates and water residence time of groundwaterfed lakes by stable isotopes of water $\left({ }^{18} \mathrm{O},{ }^{2} \mathrm{H}\right)$ and radon $\left({ }^{222} \mathrm{Rn}\right)$ mass balances, Hydrological Processes, 32, 805-816.

Popovska C. and Bonacci O. (2007), Basic data on the hydrology of Lakes Ohrid and Prespa, Hydrological Processes, 21, 658664.

Ricketts R.D. and Johnson T.C. (1996), Climate change in the Turkana basin as deduced from a 4000-year long delta 0-18 record, Earth Planet, Science Letters, 142, 7-17.

Roberts N., Jones M.D., Benkaddour A., Eastwood W.J., Filippi M.L., Frogley M.R., Lamb H.F., Leng M.J., Reed J.M., Stein M., Stevens L., Valero-Garcés B. and Zanchetta G. (2008), Stable isotope records of Late Quaternary climate and hydrology from Mediterranean lakes: the ISOMED synthesis, Quaternary Science Reviews, 27(25-26), 2426-2441.

Siegenthaler U. and Oeschger H. (1980), Correlation of ${ }^{18} \mathrm{O}$ in precipitation with temperature and altitude, Nature, 285, 189-223.

Talbot M.R. and Kelts K. (1990), Paleolimnological signatures from carbon and oxygen isotopic ratios in carbonates from organic carbon-rich lacustrine sediments, In Katz B.J. (ed.), Lacustrine Basin Exploration: Case Studies and Modern Analogues, American Association of Petroleum Geologists Memoir, 50, 99-112.

Talbot M.R. and Lærdal T. (2000), The late Pleistocene Holocene of Lake Victoria, East Africa, based upon elemental and isotopic analyses of sedimentary organic matter, Journal Paleoclimate, 23, 141-164.

Triantaphyllou M.V., Ziveri P., Gogou A., Marino G., Lykousis V., Bouloubassi I., Emeis K.-C., Kouli K., Dimiza M., Rosell-Melé A., Papanikolaou M., Katsouras G. and Nunez N. (2009), Late Glacial-Holocene climate variability at the south-eastern margin of the Aegean Sea, Marine Geology, 266(1-4), 182197.

Turner K.W., Wolfe B.B., Edwards T.W., Lantz T.C., Hall R.I. and Larocque G. (2014), Controls on water balance of shallow thermokarst lakes and their relations with catchment characteristics: a Multi-year, landscape-scale assessment based on water isotope tracers and remote sensing in Old Crow Flats, Yukon (Canada). Global Change Biology, 20, 1585-1603.

Vafeiadis P. (1983), Hydrogeological study of the Kastoria basin, Phd Thesis, Aristotle University of Thessaloniki, p. 130.

Zanchetta G., Drysdale R.N., Hellstrom J.C., Fallick A.E., Isola I., Gagan M.K. and Pareschi M.T. (2007), Enhanced rainfall in the Western Mediterranean during deposition of sapropel S1: stalagmite evidence from Corchia cave (Central Italy). Quaternary Science Reviews, 26, 279-286.

Zanchetta G., van Welden A., Baneschi I., Drysdale R.N., Sadori L., Roberts N., Giardini M., Beck C. and Pascucci V. (2012), Multiproxy record for the last 4500 years from Lake Shkodra (Albania/Montenegro), Journal of Quaternary Science, 27, 780-789. 